\title{
Histological Study of the Oesophagus and Stomach in Grey-Backed Shrike (Lanius tephronotus)
}

\author{
Estudio Histológico de Esófago y Estómago del Alcaudón (Lanius tephronotus)
}

Lei Zhu****

ZHU, L. Histological study of the oesophagus and stomach in grey-backed shrike (Lanius tephronotus). Int. J. Morphol., 33(2):459464, 2015.

SUMMARY: The microstructure of oesophagus and stomach in grey-backed shrike were examined by means of light microscopy. The results showed that the oesophagus glands were mucous glands, the shedding glandular cells and the mucin from the oesophagus glands secreted to the lumen. The number of the glands in the thoracic part was less than that of in the cervical part. The lumens of the glands showed an intense positive periodic acid-Schiff and Alcian blue reaction. There were two types of glands in the lamina propria. The simple tubular glands were located in the superficial lamella of the lamina propria, while compound tubular glands were located in the deep lamella. The epithelium was lined by a layer of cuticle in the intermediate zone between the proventriculus and gizzard. The surface of gizzard possessed a rough thick cuticle, which was made up of the Alcian blue-positive horizontal matrix and the periodic acid-Schiff-positive vertical rods.

KEY WORDS: Lanius tephronotus; Oesophagus; Stomach; Histology.

\section{INTRODUCTION}

Shrikes of the genus Lanius belong to the order Passeriformes, mainly sit-and-wait predators, often perching at the top of high grasses, bushes, telephone pole or trees while looking for moving prey (Tryjanowski \& Reino, 2004). Shrikes are interesting because they possess features of both passerines and raptors. They are called raptional birds in the order of Passeriformes, as their diets consist of small vertebrate animals, and small birds.

The digestive tract of birds shows a great diversity according to their respective feeding and dietary habits. A large body of knowledge the morphology of the alimentary tract in birds has been conducted on many big type birds, especially on fowl (Martínez et al., 2000; Rossi et al., 2005; Selvan et al., 2008; Ma, 2009; Kadhim et al., 2011), but no studies were reported on the morphology of the digestive tract of birds in the family Laniidae. Grey-backed shrike (Lanius tephronotus) is a middle-sized bird frequently seen in East Asia (Mackinnon \& Phillipps, 2000). It is mainly an eastern Palaearctic taxon and a high-elevation shrike. The aim of the present study is to give a detailed description of the histological architecture of oesophagus and stomach of the grey-backed shrike.

\section{MATERIAL AND METHOD}

Six adult birds of either sex were used in this study. They were purchased from pet stores and checked for their health status before being euthanized with ethyl ether. The handle of the specimens was approved by The Animal Experimentation Ethics Committee of Qujing Normal University. The morphological parameters were recorded with the help of measuring scale and thread vernier calipers. For the histological study, fragments of the oesophagus and the stomachs were immersed in neutral formalin for $24 \mathrm{~h}$ and then submitted to the dehydration process with alcohol and embedded in paraffin wax. The tissues were fixed in neutral buffered formalin, dehydrated, and embedded in paraffin. Histologic sections of 5-6 mm thick were obtained and stained routinely with hematoxylin-eosin (HE), periodic acid-Schiff (PAS) and combined Alcian-blue-periodic acid Schiff stain (AB-PAS). Later, the sections were analyzed in Olympus microscope, model BX50.

\section{RESULTS}

Oesophagus. The oesophagus was the beginning of the

\footnotetext{
* Key Laboratory of Yunnan Province, Universities of the Diversity and Ecological Adaptative Evolution for Animals and Plants on YuiGui Plateau. ** College of Biology and Environmental Science, QuJing Normal University, Yunnan, P. R. China.
} 
dissect tract and connected the oropharynx and the proventriculus. The length of the oesophagus was $43-44 \mathrm{~mm}$. The wall was distensible muscular organ and thin, only $0.8-$ $1.1 \mathrm{~mm}$. The crop was absent. The oesophagus was divided to two parts: the cervical part and the thoracic part, by the entrance of the thoracic. The length of the cervical part was $32-33 \mathrm{~mm}$, and the length of the thoracic part was $11-12$ $\mathrm{mm}$.

The wall of the oesophagus was constituted by the following layers: mucous membrane, muscular, and serosa. The muscous membrane, not keratinized, was lined by stratified squamous epithelium. There were 10-20 mucous glands in the lamina propria. The glands were extended from the lamina propria to the epithelium, and some occupied the whole mucous membrane (Fig. 1A). The cells lined the glandular lumens characterized as high column appearance and flat basal nucleus. The glands were surrounded by a thin layer of smooth muscle, and the cells were multilaminar in the floor of the glands. The lumens of the glands showed an intense positive PAS and $\mathrm{AB}$ reaction (Fig. 1B, C). The shedding gland cells and the mucin from the oesophagus glands secreted to the lumen, which was easy to discriminate from PAS reaction and even occupied the whole lumen of the oesophagus. The

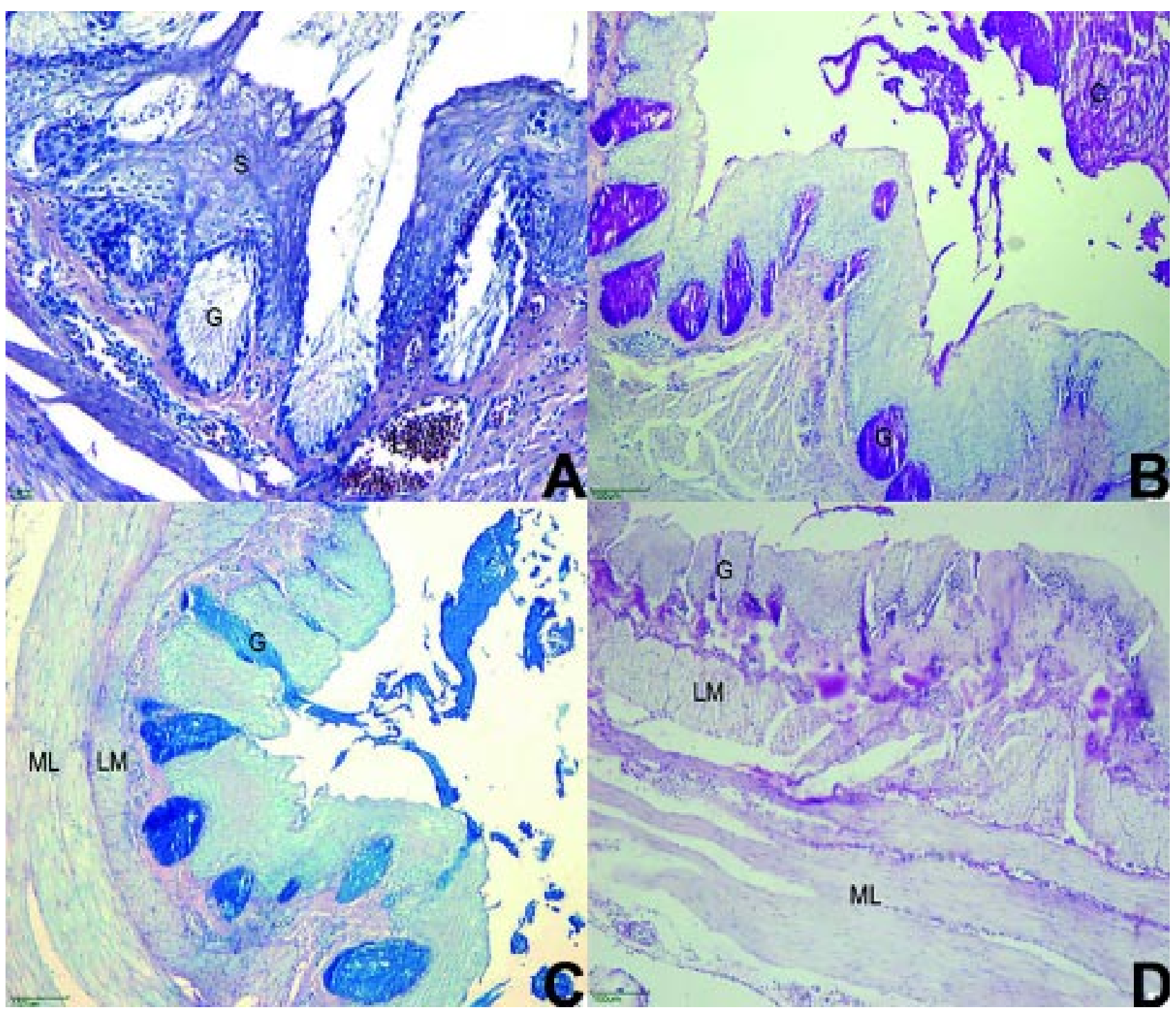

Fig. 1. The histological sections of the esophagus. A. The stratified squamous epithelium (S) of the cervical parts of the oesophagus. G, oesophagus glands; L, the lymphoid infiltration. HE Stain. X200 B The esophagus glands (G) showed a positive PAS reaction, the mucin and the glandular cells were to make up the content (C) which occupied the lumen of the organ in the cervical part of the esophagus. PAS stain X100 C The esophagus glands $(\mathrm{G})$ and the mucin showed a positive AB reaction. LM, lamina muscularis mucosa; ML, muscular layer. Combined AB-PAS stain. X100D. The mucin in the glands $(\mathrm{G})$ was all secreted in the thoracic part. LM, lamina muscularis mucosa; ML, muscular layer. PAS stain X100. 
number of the glands in the thoracic part was less than that of in the cervical part. The mucin of the esophagus glands were almost secreted in the thoracic part, leaving the smooth muscle which surrounded the glands (Fig. 1D).

The tunica submucosa was absent. The lamina muscularis mucosa was longitudinal muscle of $0.1-0.2$ $\mathrm{mm}$ in thickness. Many nodular lymphatic tissues were located upon the glands and sometimes extended into the tunica submucosa. The muscular layer was circular muscle of $0.3-0.5 \mathrm{~mm}$ in thickness. The loose connective tissue in the lamina propria showed a weak positive PAS reaction. The serosa consisted of many blood vessels and loose connective tissues.

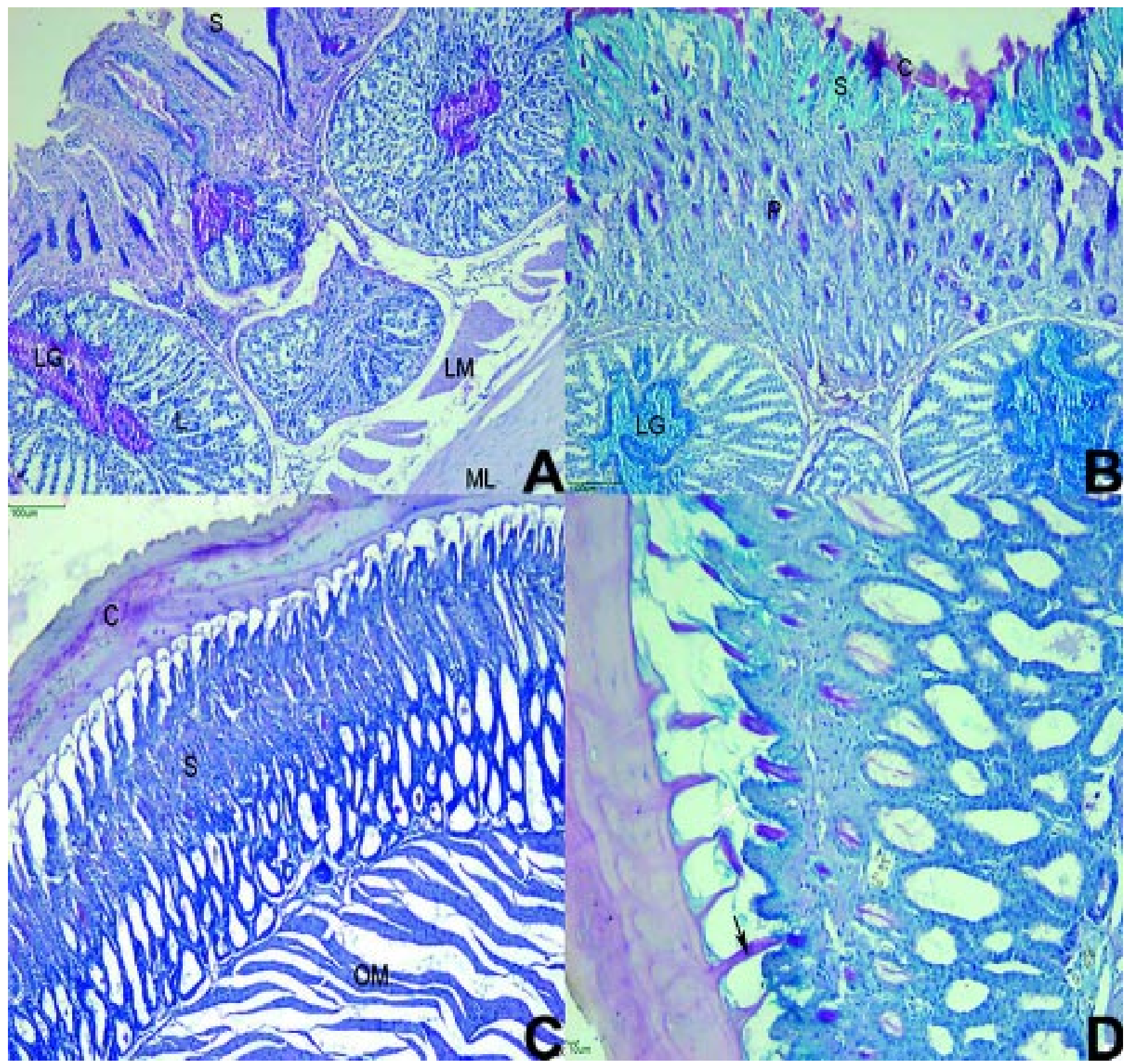

Fig. 2. The histological sections of the stomach. A. The surface of the simple tubular glands (S) and the lumen of the compound tubular glands (LG) showed a positive PAS reaction. L, lobule of proventricular glands. LM, lamina muscularis mucosa; ML, muscular layer. PAS stain X100 B.The simple tubular glands (S) and the lumen of the compound tubular glands (LG) showed an intensive positive AB reaction, while the lumen of the peacock tail-liked glands $(\mathrm{P})$ and the cuticle $(\mathrm{C})$ showed a positive PAS reaction in the junction between the proventriculus and the gizzard. Combined AB-PAS stain. X100 C The surface of gizzard possessed a rough thick cuticle (C). S, simple tubular glands; OM, oblique muscle. HE Stain. X100 D The horizontal koilin (white arrow) was AB-positive, while the vertical koilin (black arrow) was PAS-positive in combined AB-PAS stain. X200. 
Proventriculus. The mucous membrane of proventriculus threw into folds and sulci, which was lined by simple columnar epithelium. There were two types of glands in the lamina propria. The simple tubular glands were located in the superficial lamella of the lamina propria, while the compound tubular glands were located in the deep lamella. The glandular cells lining the folds and the crypts were high columnar cells, with basal nuclei and acidophilia cytoplasm. The compound tubular glands were made up of many lobules separated by a thin layer of connective tissue, and every lobule secreted mucin through one secreting duct. Every secreting duct was opened to the lumen as a papilla. The lumens of the compound tubular glands were lined by high columnar cells, with hyaline cytoplasm and flat nuclei. The cells lining the secreting ducts and the lumen showed an intense positive action in PAS reaction (Fig. 2A). Some diffuse lymphoid cells were located upon the surface glandular cells. The glandular cells were basophilia and showed a negative PAS and AB reaction. The lamina muscularis mucosae were two layers. The interior layer had variable thickness and located upon the simple tubular gland, while the outer one was a layer of discontinuous longitudinal smooth muscle and located upon the compound tubule glands. Some nodular lymphatic tissues were located in the connective tissues that separated the lobules. The submucosa layer was a layer of loose connective tissue. The muscular layer, constituted by circular muscle, was not well developed. The tunica externa was formed by connective tissue rich in blood vessels and nervous plexus.

The epithelium was lined by a layer of cuticle in the intermediate zone between the proventriculus and gizzard. The glands upon the simple tubular glands were peacock tail-liked, while the length of simple tubular glands and the thickness of the interior layer of lamina muscularis mucosae were reduced. The simple tubular glands and the lumen of the compound tubular glands showed an intensive positive $\mathrm{AB}$ reaction, while the lumen of the peacock tailliked glands and the cuticle showed a positive PAS reaction (Fig. 2B).

Gizzard. The surface of gizzard possessed a layer of rough cuticle, which was 112-140 mm thick and showed a positive PAS reaction. The epithelium showed many folds, and was lined by simple columnar cells. The cells were high columnar appearance, with basal nucleus and hyaline cytoplasm. Some crypts were in the surface of the epithelium, and the bases of the crypts were the open of the gizzard glands. The gizzard glands were simple tubular glands, located in the lamina propria. The glands were divided to two parts: cervical parts and body parts. The cervical parts were more restricted than the body parts.
The secretions in the lumen of cervical parts were eosinophilic like the cuticle. The cells in the body parts were basophilia and the lumens normally were vacant (Fig. 2C). The lamina muscularis mucosae were absent. The muscular layer was very thick and made up of interior oblique muscle and outer circular muscle. The tunica serosa was constituted by connective tissues that were rich in blood vessels and nervous plexus.

The cuticle was made up of the horizontal matrix, the vertical rods and shedding epithelial cells. The horizontal matrix was located between the cuticle and the surface epithelium, secreted by the surface glandular cells; while the vertical rods secreted by the simple tubular glands and existed in the lumen of the glands. The horizontal matrix and the vertical rods were easy to discriminate in combined AB-PAS stain, as the horizontal koilin was AB-positive, while the vertical koilin was PAS-positive (Fig. 2D). This showed that the horizontal matrix were acid and neutral mucopolysaccharide, while the vertical rods was acid.

\section{DISCUSSION}

The oesophagus in the entrance of the thoracic normally expanded to form an organ called crop. The oesophagus of the grey-backed shrike did not have crop, this was in according with the finding in other Passeriformes birds (Rajabi \& Nabipour, 2009). The crop was a storage organ where the ingested food was moistened by the mucous secreted by the oesophagus and crop glands. The food of grey-backed shrike was affluent, and they had the habit of storing the food, such as putting their food on the branches of trees, so they did not need the crop to store the food. Additionally, they had the habits of shredding food with their beaks, so their oesophagus was narrow. The wall of the oesophagus was composed of three layers: mucous membrane, muscular layer and serosa. The submucous layer was absent. This was coincided with the report of Sagsöz \& Liman (2009). But Rajabi \& Nabipour identified the submucous layer was located between the lamina muscularis mucosae and the muscular layer in the oesophagus of kestrel.

The extent of keratinization of the oesophagus epithelium differed from species (Rajabi \& Nabipour). The mucous membrane was not keratinized, which was in accordance with the findings of Ma and Sagsöz \& Liman. The esophageal glands were located in the lamina propria in birds, but in the submucosa layer in mammalians (Sagsöz, 2006). The esophageal glands occupied the whole epithelium when the sections crossed centrally the glands. The glands were simple acinar glands, but Srisai et al. (2002) found 
that the glands were branched. Rossi et al. revealed that the glands secreted through a secreting tube, but this paper had not identified the existence of the tube, and the glands were directly open to the lumen, which coincided with the result of Ma. The number of the glands in the thoracic part was less than that of in the cervical part. Rajabi \& Nabipour stated that the glands were abundant throughout the oesophagus in the House Sparrow. In the cross sections, the secretion of the glands in the cervical part characterized like this: in some regions the mucin all secreted, but in other regions the mucin still remained in the lumens of the glands. The mucin and the glandular cells were almost secreted to lubrication the food in the thoracic part, leaving the smooth muscle surrounded the glands, so the smooth muscle might play a role of crushing the glands. This might be the results of the contraction of the muscular layer. The glands and the mucin in the lumen of the organ showed an intense positive Pas and $\mathrm{AB}$ reaction, this was indicated that the mucin was acidic and neutral mucosubstances. This was similar with the findings of Rajabi $\&$ Nabipour in the Rock Dove and House Sparrow. The muscular layer was constituted by circular muscle, and this was in accordance with the finding of Srisai et al. Rossi et al. stated that on the lamina propria of the partridge oesophagus there were three layers of smooth muscle: an inner longitudinal, a medium circular and an outer longitudinal.

In birds, the stomach was divided into two parts: proventriculus and gizzard. There were two types of glands in the proventriculus. The compound tubular glands secreted the hydrochloric acid and pepsinogen. In earlier studies, the simple tubular glands were considered as artifacts of preparation (Hodges, 1974), while Ogunkoya \& Cook (2009) stated that they formed by simple invaginations of the surface epithelial cells into the lamina propria. The simple tubular glands showed an intensive positive $\mathrm{AB}$ reaction and a poor intensive positive PAS reaction. This suggested that the mucin lined the epithelium was neutral and acid mucopolysaccharide, which formed a resistant mucosal barrier to protect the epithelium (Selvan et al.). The proventriculus glands distributed throughout the entire organ, while in the ostrich the glands were located only in the papillary region (Tadjalli et al., 2011). Martínez et al. stated that lamina muscularis mucosae was discontinuous. This was in according with the finding of Ma.

The cuticle and the muscle in the gizzard played an important role of grinding food into a finely divided state. Although the diet of the grey-backed shrike consisted of small rodents and small-sized birds, insects comprised most of their diet, especially insects in the Coleoptera order. So they were actually insectivorous birds. Additionally, the diet of greybacked shrike consisted of some seeds. So the existence of the cuticle was essential. The thickness of the cuticle was $112-140 \mathrm{~mm}$, but that of the Tinamou was $243-534 \mathrm{~mm}$
(Chikilian \& De Speroni, 1996). The horizontal matrix was AB-positive, while the vertical rods were PAS-positive, and this coincided with the finding of Selvan et al.

Eidaroos et al. (2008) found that the mucosa of proventriculus was covered externally by thin layer of cuticle, but this report had identified the existence of the cuticle only in the intermediate zone between the proventriculus and gizzard. The cuticle was made up of the horizontal matrix and the vertical rods. The mucin secreted from the lumen of simple tubular glands were hardening to form the vertical rods. The lumen and luminal border of the simple tubular glands in the proventriculus showed PAS positive material like in the simple tubular glands in the gizzard. The horizontal matrixes were made up of the mucin secreted by the surface cells and the crypt cells. The mucin spread all over the epithelium and was then hardened by the hydrochloric acid secreted by the proventriculus. The simple tubular glands in the proventriculus were open and the sulci in the epithelium of proventriculus were deeper than those of gizzard, so the mucin could not connect together to form the horizontal matrixes. But the simple tubular glands in the junction of the proventriculus and gizzard, which Selvan et al. and Kadhim et al. called the proprial glands, were separated by the connective tissues to form peacock taillike glands,. This structure made the vertical rods form gradually and merge with the horizontal matrix. The number and the thickness of the peacock tail-like glands might be essential for the form of the cuticle in the junction of the proventriculus and gizzard. The material in the lumen of the peacock tail-like glands showed PAS positive. This was similar with the results of Selvan et al. and Kadhim et al. Eidaroos $e t$ al. stated that the gizzard glands were branched glands and simple tubular glands, but this reports has not found branched glands. Eidaroos et al. and Kadhim et al. found that the glands terminated at a layer of dense connective tissue known as tela submucosathis. Ma founded the thickness of this layer was $360.51 \mathrm{~mm}$. This paper has not identified the existence of this layer. The gizzard did not have the lamina muscularis mucosae and tunica submucosa, and the simple tubule glands were directly merged with the tunica muscularis.

\section{ACKNOWLEDGMENTS}

The study was supported by Scientific Foundation of Qujing Normal University (2009ZD005) and the National Natural Science Foundation of China (31260087 to L-Z Tang). I am grateful to Key Subject of Ecology and Animal Sience Teaching Team in QuJing Normal University, Assistant for their technical help. 
$\overline{\text { ZHU, L. Estudio histológico de esófago y estómago del alcaudón }}$ (Lanius tephronotus). Int. J. Morphol., 33(2):459-464, 2015.

RESUMEN: La microestructura del esófago y el estómago del alcaudón gris fueron examinados mediante microscopía de luz. Los resultados mostraron que las glándulas del esófago eran glándulas mucosas, y que las células glandulares de descamación y la mucina de las glándulas del esófago eran secretadas al lumen. El número de glándulas en la porción torácica del esófago fue menor que en la porción cervical. Las aberturas de las glándulas mostraron una reacción positiva intensa al PAS y azul de Alcián. Se encontraron dos tipos de glándulas en la lámina propia. Las glándulas tubulares simples se localizaron en la lámina superficial de la lámina propia, mientras que las glándulas tubulares compuestas se hallaron en la lámina de profundidad. El epitelio se encontró revestido por una capa cuticular en la zona intermedia entre el proventrículo y la molleja. La superficie de la molleja presentó una cutícula gruesa, demostrada por una matriz horizontal positivo para azul de Alcian y varillas verticales positivas para el PAS.

PALABRAS CLAVE: Lanius tephronotus; Esófago; Estómago; Histología.

\section{REFERENCES}

Chikilian, M. \& De Speroni, N. B. Comparative study of the digestive system of three species of tinamou. I. Crypturellus tataupa, Nothoprocta cinerascens, and Nothura maculosa (Aves: tinamidae). J. Morphol., 228(1):77-88, 1996.

Eidaroos, H.; Yoshimura, Y. \& Helmy, S. A. Distribution of the ghrelin hormone producing cells in the gastro-intestinal tract of some birds (immunohistochemical study). J. Vet. Anat., 1(1):14-21, 2008.

Hodges, R. D. The histology of the fowl. London, Academic Press, 1974. pp.35-88.

Kadhim, K. K.; Zuki, A. B.; Noordin, M. M. \& Babjee, S. M. Histomorphology of the stomach, proventriculus and ventriculus of the red jungle fowl. Anat. Histol. Embryol., 40(3):226-33, 2011.

Ma, G. T. Morphological and histological observation on the esophagus and stomach of Tetraogallus himalayensis. Chin. J. Zool., 44(5):124-7, 2009.

Mackinnon, J. \& Phillipps, K. A field guide to the birds of China. Oxford, Oxford University Press, 2000. pp.237-40.

Martínez, A.; López, J. \& Sesma, P. The nervous system of the chicken proventriculus: an immunocytochemical and ultrastructural study. Histochem. J., 32(1):63-70, 2000.

Ogunkoya, Y. O. \& Cook, R. D. Histomorphology of the proventriculus of three species of Australian passerines:
Lichmera indistincta, Zosterops lateralis and Poephila guttata. Anat. Histol. Embryol., 38(4):246-53, 2009.

Rajabi, E. \& Nabipour, A. Histological study on the oesophagus and crop in various species of wild bird. Avian Biol. Res., 2(3):161-4, 2009.

Rossi, J. R.; Baraldi-Artoni, S. M.; Oliveira, D.; da Cruz, C.; Franzo, V. S. \& Sagula, A. Morphology of glandular stomach (Ventriculus glandularis) and muscular stomach (Ventriculus muscularis) of the partrigde Rhynchotus rufescens. Cienc. Rural, 35(6):1319-24, 2005.

Sagsöz, H. Structural properties of oesophagus in the mammalian and avian species. Saglık Bilimleri Dergisi, 15(3):203-7, 2006.

Sagsöz, H. \& Liman, N. Structure of the oesophagus and morphometric, histochemical-immunohistochemical profiles of the oesophageal gland during the post-hatching period of Japanese quails (Coturnix coturnix japonica). Anat. Histol. Embryol., 38(5):330-40, 2009.

Selvan, P. S.; Ushakumary, S. \& Ramesh, G. Studies on the histochemistry of the proventriculus and gizzard of post-hatch guinea fowl (Numida meleagris). Int. J. Poult. Sci., 7(11):11126, 2008 .

Srisai, D.; Juntaravimol, S.; Pongkete, P.; Koonjaenak, S. \& Suprasert, A. Histological and histochemical studies on esophagus of the germain's swiftlet (Collocalia german oustalet, 1878). J. Kasetsart Vet., 12(2):16-21, 2002.

Tadjalli, M.; Parto, P. \& Shahraki, A. F. Histological study of proventriculus of male adult ostrich. Glob. Vet., 7(2):108-12, 2011.

Tryjanowski, P. \& Reino, L. M. Post-breeding habitat selection of the Grey-backed Shrike (Lanius tephronotus) in Sichuan, China. Biol. Lett., 41(2):195-7, 2004.

Correspondence to:

College of Biology and Environmental Science,

QuJing Normal University

QuJing

Yunnan, 655011

P. R. CHINA

Tel.: +86-0874-8998627

Email: zamlx@163.com

Received: 24-08-2014

Accepted: 28-02-2015 